\title{
The impact of the economic system on social and labour relations in the early church as revealed in the letter of James
}

\begin{abstract}
Author:
Dirk G. van der Merwe ${ }^{1}$

Affiliation:

${ }^{1}$ Department of Christian Spirituality, Church History and Missiology, University o South Africa, South Africa

Correspondence to: Dirk van der Merwe

Email:

vdmerdg@unisa.ac.za

Postal address:

189 Kotie Ave, Murrayfield

0184 Pretoria, South Africa

Dates:

Received: 19 Oct. 2011

Accepted: 13 June 2012

Published: 17 Sept. 2012

How to cite this article: Van der Merwe, D.G., 2012, 'The impact of the economic system on social and labour relations in the early church as revealed in the letter of James', Verbum et Ecclesia 33(1), Art. \#691, 12 pages. http://dx.doi.org/10.4102/ ve.v33i1.691
\end{abstract}

The Letter of James addresses the dichotomy between the socioeconomic classes of the rich

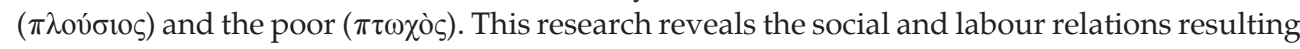
from this dichotomy and the wealth of socioeconomic data contained in this letter. The rich are alerted to the consequences of their unrighteousness towards the poor, and the poor receive exhortations of encouragement. The metaphoric use of 'richness' is also examined. This research focuses on the socioeconomic activities and attitudes that this dichotomy prompted during the second part of the first century, and it indicates how the economic system impacted on and influenced the lives of the early Christians in the 1st century Mediterranean world. James bounces these questions around to cast the rich, as well as the Christian assembly, in a bad light for condoning the mistreatment of the poor. His three rhetorical questions are quite to the point and are meant to be answered affirmatively.

\section{Introduction}

The Letter of James consistently refers to only two economic classes ${ }^{1}$ : the rich ( $\dot{0} \pi \lambda$ ov́ $\left.\sigma 10 \varsigma\right)$ and the poor (ó $\pi \tau \omega \chi \grave{o} \varsigma)(1: 9-11 ; 2: 2-6 ; 5: 1)$. In the ancient Greco-Roman world, prosperity and poverty existed side by side. The gap between the rich and the poor widened during the Hellenistic and Roman eras, with unfortunate consequences. A question that usually arises in church circles is: What effects did the ancient economy have on the early church? These effects seem to be clear from the short letter of James in which he says much about the impact of the economic system on social and labour relations. His main concern is with the dichotomy between the two socioeconomic classes of the rich and the absolutely poor as well as with the prejudiced attitudes of some members in the church towards the poor.

This research focuses on the socioeconomic activities and attitudes that this dichotomy prompted during the second part of the first century, and it indicates how the economic system impacted on and influenced the lives of the early Christians in the 1st century Mediterranean world. Passages from the letter relevant to this investigation are $1: 2-8 ; 2: 1-7,15-16 ; 3: 13-16 ; 4: 1-10,13-16$ and $5: 1-8$. These passages will also be dissected into smaller relevant units. The research concludes by looking at the fate of the unjust rich and by exhorting the poor to be strong.

\section{Social and labour relations between the two economic classes}

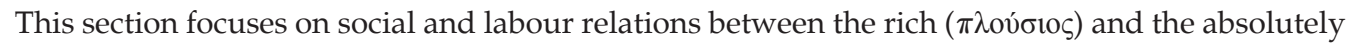
poor $(\pi \tau \omega \chi \grave{o} \varsigma){ }^{2}$ We shall discuss how some early Christians discriminated against the poor and how the poor $(2: 1-4,6 ; 3: 13-16 ; 4: 13-16 ; 5: 4-6)$ were dishonoured and harmed by the rich. Although this was a cause for concern, the poor did not resist physically but sought comfort in the Lord of hosts (5:4).

\section{The rich}

\section{Dishonouring of the poor}

Has not God chosen the poor ( $\tau$ ov̀ $\pi \tau \omega \chi 0 \mathrm{y} \varsigma$ ) in the world to be rich in faith and to be heirs of the kingdom that he has promised to those who love him? But you have dishonoured the poor ( rich (oi $\pi \lambda$ ov́бıt) who oppress you? Is it not they who drag you into court? Is it not they who blaspheme the excellent name that was invoked over you? (Ja 2:5-7)

1.The addressees of James are clearly and thoroughly distinguished by the author of this article in his publication: Van der Merwe (2010:18-46). There he also highlights the matter of the rhetorical argument of the Letter of James when dealing with the rich and the (2010:18-46). There he also highlights the matter of the rhetorical argument of the Letter of James whe
poor. Because it has been done thoroughly, he does not see the necessity of repeating it in this article.

2.The early church in Jerusalem, according to Paul and Acts, faced problems regarding the rich and the poor (see GI 2:10; 2 Cor 8-9; Rm 15:22-29; Ac 2:44-5, 5:1-11, 11:29; cf. also Keck 1965:100-129. 
In chapter one, the author (hereafter James) ${ }^{3}$ starts with a general comparison between the rich and the poor. In James 2:6a, the author becomes more specific and outlines the treatment of the poor by some church members (Lea 1999:282). ${ }^{4}$ James points out that God has chosen the poor (v. 5),

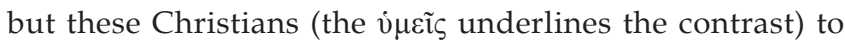
whom James addresses his letter have dishonoured them. ${ }^{5}$ These Christians discriminate against the poor, and they do so in favour of the rich. This means that they are siding with the very class which both persecuted and continues to persecute the impoverished believers. Influenced by the rich, these Christians turned the church into a device of persecution (Davids 1982:112; cf. also Loh \& Hatton 1997:69). Moo (2000:108) makes the important point that James is not counselling the Christians to be unkind to these rich people. He is simply arguing that they should not afford them undue esteem at the expense of the poor.

The first reason that James gives for prohibiting discrimination against the poor is that it manifests an attitude contrary to the attitude of God. His second reason, stated in 2:6b-7, comprises three parallel and related questions. The rich people have mistreated the poor in the following ways, which he describes here in terms of three rhetorical questions (Loh \& Hatton 1997:69; Moo 2000:108) with regard to the dishonouring $^{6}$ of the poor ${ }^{7}$ :

- Is it not the rich who oppress you? (oppression)

- Is it not they ... who drag you into court? (legal persecution)

- Is it not they ... who blaspheme the excellent name that was invoked over you? (blasphemy)

James bounces these questions around to cast the rich, as well as the Christian assembly, in a bad light for condoning the mistreatment of the poor. ${ }^{8}$ His three rhetorical questions are quite to the point and are meant to be answered affirmatively. ${ }^{9}$ The first rhetorical question concerns the oppression of the poor by the rich. According to Dibelius (1976:138), this oppression refers to 'social oppression'. James adopts the verb $\kappa \alpha \tau \alpha \delta v v \alpha \sigma \tau \varepsilon v ́ \omega$ (oppress) $^{10}$ from the LXX. It is a term the prophets were famous for using in their denunciation 3.Although there is no certainty about the identity of the author, I shall refer to him
or her as 'James'.

4.Also Richardson 2001:116; Loh \& Hatton 1997:69; Kistemaker 1984:78.

5.See Martin 2002:26 about the use of 'the rich' (oi $\pi \lambda$ ov́ $\sigma 101$ ) in James.

6.Loh \& Hatton (1997:69) express dishonoured as 'you have made the poor lose face' or 'you have taken away the face of the poor'.

7.In this pericope (2:5-7), one actually finds four rhetorical questions, each of which assumes an affirmative answer (McKnight 2011:191). The first one will be discussed separately under the heading 'Metaphoric use of economic concepts and terminology' due to the positive nature of the question as opposed to the negative nature of the last three questions.

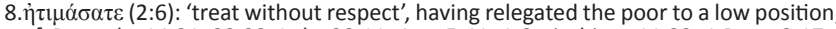
cf. Proverbs 14:21, 22:22; Luke 20:11; Acts 5:41; 1 Corinthians 11:22; 1 Peter 2:17.

9.According to this verse, the acts of violence were not limited to a single event but involved multiple occurrences (Lea 1999:343).

10.Scholars define this as 'to tyrannize, to exercise inordinate power over others' (MacArthur 1998:110); 'to exercise power over' (Friberg, Friberg \& Miller 2000:217); to 'act violently' (Balz \& Schneider 1993:(2)257); to 'oppress, exploit, 2000:217); to 'act violently' (Balz \& Schneider 1993:(2)257); to 'oppress, exploit, rich as a class acts in this way. This verb appears otherwise only in Acts 10:38. Cf. Amos 8:4; Micah 2:2; Matthew 13:22, 19:23, 20:25; 1 Timothy 6:9; Sir 13.3-7; Cf. Amos $8: 4 ;$
Wis 2.10 . of social injustice committed by the rich against the poor, widows and orphans. ${ }^{11}$

The Christian assembly failed to confront the rich about all the ways in which they contravened the principles of justice and fairness by defrauding others of what was due to them. In fact, the Christian assembly are the ones who are being exploited by the rich. ${ }^{12}$ They are part of those whom the rich are oppressing. They are being robbed of the few possessions they have.

The second rhetorical question considers how the rich 'persecuted'13 early Christians into court. ${ }^{14}$ Whether or not these wealthy people were members of the church (though 2:4 seems to include the rich man among the 'yourselves'

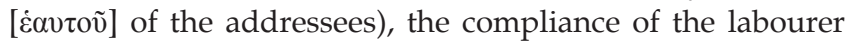
and craftsman in tolerating the wickedness of the rich went too far. Even the judges in the courts were influenced by the evil designs of the rich. They definitely used their wealth and influence with the courts to secure favourable verdicts against the poor (Moo 2000:109). James spoke out strongly against this lack of morality on the part of both the rich and the judges.

A third rhetorical question, posed in this verse, is: 'Is it not they who blaspheme ${ }^{15}$ the excellent name that was invoked over you?' This refers to the name of the Lord, whether God the Father or Christ, ${ }^{16}$ which again signifies that God and his people, mutually, belonged to one another. By offending poor Christians in the courts of law and treating them as though they were criminals and thieves, it was as though the rich were attacking the Lord. In performing such acts, the rich who were Christian believers were no better than the Gentiles as they had sinned against the poor without defending them. The honourable name of the Lord was dishonoured by reprehensible practices that had stemmed from playing favourites with the rich. Hence, favouritism

11.See Amos 8:4 (oppression of the poor); Jeremiah 7:6 (oppression of the stranger orphan, widow); Ezekiel 18:12 (oppression of the poor and needy). Cf. Wis 2:10 (oppression of the righteous poor). The fact that the pronoun vuñv is used (oppression of the righteous poor). The fact that the pronoun $\mu_{\mu} \tilde{\omega} v$ is used indicates that the readers ranked with the poor (Sidebottom 1967:41; see also
Davids 1982:112; Martin 2002:66). They probably belonged to the class of poor agricultural labourers (Moo 2000:109). For Richardson (2001:116), James's readers rather belong to a 'middle class'.

12.The article by Stulac (1990) raised serious questions about whether or not the rich in James can be regarded as Christian. James offered no clear distinction between the rich person and the Christian. The brethren came from every economic stratum. The rich as a class committed injustices by their acts of neglecting and exploiting the poor. According to James, the Christians were also guilty of these transgressions. See also McNight (2011:197f).

13. $\ddot{\lambda} \lambda \omega$ : 'as a legal technical term lead by force, drag into court' (Friberg, Friberg \& Miller 2000:144); 'lead by force' (Swanson 1997:1816.5.2). James also presented the complicity of the judges in this activity (cf. Ac16:19; 1 Cor 6:2).

14.Whilst Acts records instances of persecution by the rich (e.g. the Sadducees of Ac 4:1, 13:50; the owners in Ac 16:19), the probable reference is to being hauled before the synagogue courts (the legal basis for 1 Cor $6: 2,4$; the other NT use of крıт́ prov) or other local jurisdictions for civil actions to rob the Christians 'legally' of what was rightfully theirs (Davids 1982:112).

15. $\beta \lambda \alpha \sigma \varphi \eta \mu \varepsilon ́ \omega:$ 'To blaspheme, revile. To hurt the reputation or smite with reports or words, speak evil of, slander, rail' (Zodhiates 2000:G987). 'The blasphemy does not have to find verbal expression. Any bad or unloving action can contain it, either because it resists the holy will of God or because it causes the enemies of Christianity to calumniate it' (Beyer 1976:[1]624); 'to speak in a disrespectful way that demeans, denigrates, maligns' (Danker 2000:178).

16.McKnight (2011:198) (also Richardson 2001:117f) opts for a reference to Jesus the Messiah because this was a Messianic community. See also Philippians 2:9-11. See McKnight (2011:199-202) for a thorough and convincing discussion of the messianic meaning of this name. See also the discussion by Loh \& Hatton (1997:71) for an alternative understanding. 
(cf. also 2:1-4) was a complex sin amongst these Christians (Richardson 2001:116). Thus to honour the rich was to dishonour Christ or God.

\section{Fraud against the poor}

'Look! The wages of the laborers who mowed your fields, which you kept back by fraud (ó $\alpha \pi \varepsilon \sigma \tau \varepsilon \rho \eta \mu \varepsilon ́ v o \varsigma)$, cry out ...' (Ja 5:4). In 5:1-6, a new group of people is addressed. They are the rich agriculturalists whose grievous sin lies in how their misconduct affects others (Martin 2002:182). Their condoning the mistreatment amounts to fraud against the poor. They are guilty of not paying those who work ${ }^{17}$ for them.

The biblical view of economic justice, the command against withholding the wages of the labourers, originates in Judaism in the Mosaic laws: 'Do not defraud your neighbour or rob him. Do not hold back the wages of a hired man overnight' (Lv 19:13; cf. also Dt 24:14f; Ml 3:5).$^{18}$ This biblical view states explicitly that the profits and benefits of property owners, beyond their own basic livelihood, are secondary to paying the necessary wages to persons who are employed by them. The Old Testament calls on people to 'act justly' (Mi 6:8).

With the imperative verb, used as a demonstrative particle 'Look!'19 (cf. 3:4-5; 5:7, 9, 11), James directs the attention of the unjust rich to the evidence against them (cf. Loh \& Hatton 1997:170). The rich landowners kept ( $\dot{\alpha} \pi \varepsilon \sigma \tau \varepsilon \rho \eta \mu \varepsilon ́ v o \varsigma$, literally 'stolen' $)^{20}$ the wages that were due to these labourers (Richardson 2001:209; also Loh \& Hatton 1997:172). The wages $^{21}$ never passed out of the vault. This economic oppression was particularly severe because many of the field labourers of the ancient world were transients (cf. Moo 2000:216). ${ }^{22}$ They were often in need of special compassion because of their foreign status (cf. Geyser 1975:25-33). ${ }^{23}$

\section{Harm done by the employer}

'You have lived on the earth in luxury and in pleasure; you have fattened your hearts in a day of slaughter. You have condemned and murdered the righteous one ...' (Ja 5:5-6). This is the third indictment of James against the heartlessness of the rich. It deals with their luxurious lifestyle and disregardful mistreatment. He does not condemn the

17. غ̇ pyó $\tau$ tn: 'workman', 'labourer', especially in agriculture; cf. Matthew 9:37; Luke 10:2. 'Hired farm workers' (Loh \& Hatton 1997:171)

18.Cf. the very fine work of Johnson (1982:391-401); also Loh \& Hatton (1997:170) This equation of economic injustice and murder is anticipated in intertestamental Jewish literature. The apocryphal book of Jesus ben Sirach declares, 'He that taketh away his neighbour's living slayeth him; and he that defraudeth the labourer of his hire is a blood shedder' (34:21-22).

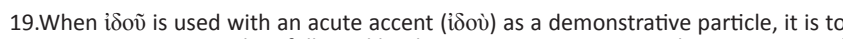
prompt attention. When followed by the nominative case, as in the text, it is used to designate what is being pointed out; pay attention, (you) see, look (Friberg, Friberg \& Miller 2000:202; Danker 2000:468)

20. $\dot{\pi} \pi \circ \sigma \tau \varepsilon \rho \varepsilon \varepsilon^{\prime}$ : to be kept back by fraud, as spoken of a thing (Ja $\left.5: 4\right)$, wages held back by fraud (Zodhiates 2000:G650); wages stolen or held back from the workers (Danker 2000:121). Also cf. Mark 10:19; 1 Corinthians 6:7-8; 7:5; Nehemiah 9:20.

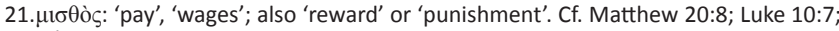
John 4:36; Acts 1:18; 2 Peter 2:15; Wis 10:17.

22.The labourers expected their pay promptly at the end of each day. They needed a steady income to provide 'daily bread' for themselves and their family (Moo 2000:216).

23.See Philo's (1995a) 'Allegoric interpretation III'. lifestyle of the rich as evil. According to the context, the rich engage in self-indulgence without caring for the poor (Loh \& Hatton 1997:173; Richardson 2001:212). An analysis of this text points out two things done by the rich employers. The first relates to themselves and the second to the poor employees. ${ }^{24}$ These crude references at the end of the epistle are also biarticulated:

1. The rich: You have lived on the earth in luxury and in pleasure; you have fattened your hearts in a day of slaughter.

2. The poor: You have condemned and

............. murdered the righteous one ...

This condemnation of James is directed against the heartlessness of the rich. Their cruelty is rooted in their self-centred pleasure and luxury at the expense of their

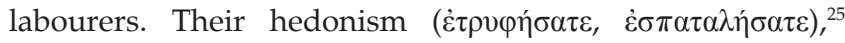
revelling in earthly pleasures, was universally condemned in the ancient world. Its offensiveness here stems not only from the unseemliness of self-indulgence but rather from the lack of concern and the lack of sympathy to the needs and sufferings of others that a life of pleasure always entails. Living luxuriously was regarded by the ancient moralists as a source of moral negligence and indecisiveness in those situations in which ethical firmness was required. But James also adds the physical aspect. He accuses the rich of having fattened themselves up by living lavishly every day. ${ }^{26}$ All Christians are to resist uncontrolled ethical and physical behaviour and to move out of a self-satisfying life. They must encounter the lives of those who barely survive so that they (the poor) too might achieve a level of wellbeing (Richardson 2001:212).

James adds one final, conclusive charge against the rich. It rounds off the passage and acts as a bridge to the next section of the book. 'You have condemned and murdered the righteous one!' (Ja 5:6). This statement clearly refers to a judicial 'murder'. The rich abuse the legal system for their own gain. It is possible that the courts deprived the poor ${ }^{27}$ of their livelihood by confiscating their farms or other means of support (Loh \& Hatton 1997:175; cf. also Martin 2002:181;

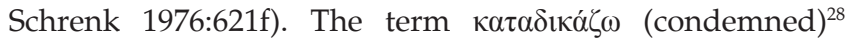
is forensic enough to be parallel to the similar charge in

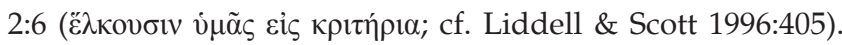

24.Although these infringements reflect an attitude of self-indulgence, they will be dealt with under 'social and labour relations' and not 'attitudes', because of the deeds (results) connected to them.

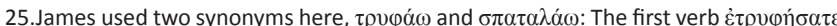
has a negative connotation in the New Testament (Lk 7:25; $2 \mathrm{Pt} 2: 13$ ). James clearly
uses it here to depict a sinful, self-indulgent lifestyle: 'lead a life of luxury' or 'selfuses it here to depict a sinful, self-indulgent lifestyle: 'lead a life of luxury' or 'self-
indulgence'; 'revel'; 'carouse'; (Martin 2002:179). Cf. also Nehemiah 9:25; Isaiah indulgence'; 'revel'; 'carouse'; (Martin 2002:179). Cf. also Nehemiah 9:25; Isaiah $66: 11$; Sir 14.4; Josephus Ant. 4.167; Herm. Sim. 6.4.1f.; 6.5.3-5. The second verb
$\dot{\varepsilon} \sigma \pi \alpha \tau \alpha \lambda \eta \eta^{\prime} \sigma \alpha \tau \varepsilon$ is more exclusively negative. Its occurrence in 1 Timothy 5:6 (cf. Ezk $\dot{\varepsilon} \sigma \pi \alpha \tau \alpha \lambda \eta \dot{\sigma} \sigma \alpha \tau \varepsilon$ is more exclusively negative. Its occurrence in 1 Timothy $5: 6$ (cf. Ezk
$16: 49$; Barn. 10.3) describes the self-indulgent widow who 'lives for pleasure' as being dead even though she is alive (see Loh \& Hatton 1997:173; Moo 2000:217).

26.See Loh \& Hatton (1997:174) for a good explanation.

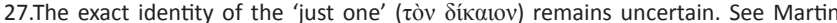
(2002:181) for a thorough discussion on this.

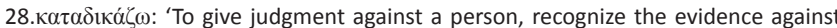
him, pass sentence, condemn' (Zodhiates 2000:G2613). Here in James 5:6, it refers to the 'hard-hearted rich who secure the condemnation of the innocent poor by an abuse of justice' (Schrenck 1976:[3]622); 'to judge someone as definitely guilty and abuse of justice' (Schrenck 1976:[3]622); 'to judge someone as definitely guilty and
thus subject to punishment - "to condemn, to render a verdict of guilt, condemnation"' (Louw \& Nida 1996:[1]555) 
The use of the verb povevi $\omega$ (murder) ${ }^{29}$ gives James's moral estimate of the result of the judicial process, an evaluation made repeatedly of the legal assaults of the rich on the poor in the Jewish piety-poverty tradition. ${ }^{30}$

Hence, these rich people, who pursue pleasure and luxury, in the end descend into a vain attempt to satisfy their greedy desires. Paul describes such people as dead even while they are alive (1 Tm. 5:6; cf. MacArthur 1998:247).

\section{The poor}

James does not only criticise the 'rich'; he also reflects on the acts of the poor in these circumstances.

He points to the passive resistance of distressful harvesters (5:4-6): ' $\ldots$ and the cries ( $\alpha i$ Bo $\alpha i)$ of the harvesters ( $\tau \tilde{\omega} v$ $\theta \varepsilon \rho ı \sigma \alpha v \tau \omega v)$ have reached the ears of the Lord of hosts (кvpíov $\sigma \alpha \beta \alpha \omega \theta)^{6} \ldots$ the righteous one, who does not resist (ov̉

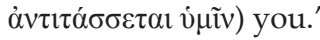

The withholding of wages by the rich employers, as described in a previous subsection, is wrong. It is listed amongst the worst deeds known to Israel and is now condemned equally harshly in the New Testament. The difference is that, here in James, the harvesters ${ }^{31}$ cry out about this injustice done to them by the rich - now their voices are heard. The cries

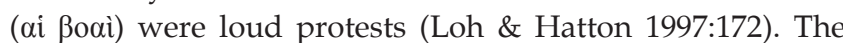
harvesters did not seek fair compensation from the rich. Probably seeking compensation would not have helped. The

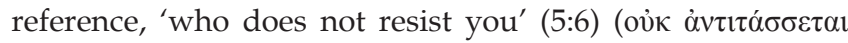
$\dot{v} \mu \mathrm{i} v),{ }^{32}$ is normally read as a statement referring to the nonresistance of the righteous in the tradition of the gospel..$^{33}$ The poor employees were right not to oppose the rich employers and evildoers who had mistreated them (cf. Mt 5:39). ${ }^{34}$ Their innocence became the final indisputable piece of evidence against the rich who had brought about many of their deaths by a continual lust for more wealth.

In this situation, they did not actively resist, yet they resisted in a passive sense (see Lea 1999:343). They turned to God who would hear them, and they referred to him as 'the Lord of

29. povevo: 'refers to the destructive injustice of the rich and powerful over and against the oppressed and powerless poor' (Balz \& Schneider 1993:[3]436); 'to deprive a person of life by illegal, intentional killing - "to murder, to commit murder"' (Louw \& Nida 1996:[1]237). 'Murder', 'kill'; the word is used in the LXX in the commandment of Exodus 20:15, 'You shall not commit murder.' Cf. Proverbs 1.32. Matthew 5:21, 19:18, 23:31, 35. Barn. 19.5. Did. 2.2. 1 Clem 57.7. Imery of the 'slaughter' of the rich is found in 1 Enoch (94.7-9; cf. 96.8; 97.8-10; 99.15).

30. See Ps 9:18; 10:8-9; 37:14, 32, 35; Proverbs 1:11; Isaiah 3:10, 14; 57:1; Amos 2:6; 5:12; 1 Enoch 96:5, 8; 98:12; 99:15; 103:15; Wis 2:10-20; cf. Davids 1982:179. However, the suffering caused to the poor by unjustly withholding wages could also have caused many of their deaths.

31.These workers may formerly have been small landowners who had had their farms swallowed up by the large landowners (Martin 2002:178).

32. $\alpha v \tau \imath \tau \alpha ́ \sigma \sigma \omega:$ : is used metaphorically to set oneself in opposition to or in array against, to resist' (Zodhiates 2000:G498); 'to oppose someone, involving not only a psychological attitude but also a corresponding behaviour - "to oppose, to be hostile toward, to show hostility"' (Louw \& Nida 1996:[1]491).

33.Isaiah 53:7; Matthew 5:39; Romans 12:14, 19; 1 Peter 2:23; Hermas Man. 8.1.10 cf. Lea 1999:343; Moo 2000:219.

34.The translation of the NIV and its theological import is followed here rather than the interpretation suggested by Schökel (1973) who argues that the final phrase of this verse should be understood as a question: 'Does not [God] oppose you?' Loh \& Hatton (1997:176) agree that this could be rendered to be a rhetorical question. hosts'. God, the Lord 'Sabbaoth'35 is best translated as 'Lord of the armies'. In the life of Israel, this address characterised God as the one who moves to deliver his people. Now this Lord and his forces will come to defend the oppressed amongst his people on the last day. ${ }^{36}$ Hence, the poor must put their trust not in people, expectations and help, but in the Lord.

\section{Section conclusion}

In this section, it was pointed out how James used a variety of harsh terms to depict the destructive acts of the rich towards the poor, only to enrich themselves. His reference to this was not only to bring these acts to light, but also to condemn them. The activities of the rich included oppression, persecution (being taken to court), blasphemy, fraud, harm, condemnation and murder.

The poor, in contrast, did not retaliate against this conduct of the rich, but turned to the Lord of hosts whom, they believed, would hear their cries and would act against this injustice.

\section{Attitudes regarding economics}

This section concentrates on the different attitudes of the rich and the poor in these socio-economic circumstances. James points to the self-directed attitudes of the rich and their disregard for the poor who has to cope with their circumstances. These attitudes can be negative, positive or antithetical.

\section{Negative attitudes}

\section{External judgement of people, due to their posture, is wrong}

... For if a person with gold rings and in fine clothes comes into your assembly, and if a poor person in dirty clothes also comes in, and if you take notice of the one wearing the fine clothes and say, 'Have a seat here, please', while to the one who is poor you say, 'Stand there', or, 'Sit at my feet', have you not made distinctions among yourselves, and become judges with evil thoughts? (Ja 2:1-4)

In this periscope, James points out that discrimination against others is incompatible with faith in Jesus Christ. In verse 2 , he proceeds to give an example. ${ }^{37}$ It is clear that James is drawing a vivid illustration in which the categories of 'rich' and 'poor' are understood more in their sociological sense than religiously or economically. James is interested in the sociological antithesis (rich or poor) with emphasis on the partiality shown to the former (cf. Maynard-Reid 1987:59). In this text, James protests against the actions of those Christians

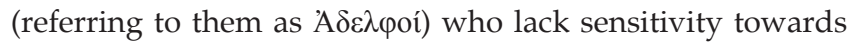
the poor. Therefore, he envisages a display of prejudice on

35. $\alpha \alpha \beta \alpha \omega \theta$ : 'Sabaoth', plural form of 'army'; typically found in the expression "the Lord of hosts'; cf. Isaiah 6:3; Romans 9:29; 1 Clem 34.6.

36.Cf. Jeremiah 22:13; 1 Enoch 47.1-4; 97.5-10.

37.Loh \& Hatton (1997:61) point out that the conjunction 'for' (v. 2) is used here to explain what is said in verse 1 , and it therefore has the force of 'to illustrate' or 'for instance'. The if-clause can be taken as the subordinate clause of the long conditional sentence here and verse 4 'have you not ...' as the main clause. If points to a hypothetical situation, especially with the exaggerated details in the example. 
the part of some in favour of the rich. His illustration and orientation here demonstrate that the actions of those who lack sensitivity towards the poor are far from 'religion that is pure and true before God and the Father' (1:27).

James uses the phrase $\dot{\varepsilon} v \pi \rho 0 \sigma \omega \pi 0 \lambda \eta \mu \psi i ́$ is (respect of persons, 2:1) to express the idea 'with actions of partiality', that is 'to make unjust distinctions between people by treating one person better than another - to show favoritism, to be partial, partiality' (Louw \& Nida 1996:[1]767). In his employment of the plural, he gives the impression that there are manifestations or varied forms of partiality that are practised in the community (Maynard-Reid 1987:50). ${ }^{38}$ Davids (1982:107) (also Moo 2000:102) feels that the example cannot be divorced from the local conditions within James' community. It is possible that his readers are also engaged in discrimination. What is necessary is for the readers to find the meaning of the example and consequently understand the type of situation being depicted here (Sidebottom 1967:38). ${ }^{39}$

James presents a likely case of unjust discrimination (2:6-7). ${ }^{40}$ The congregation is in the unpleasant position of seeking the favour of the rich and disregarding the neediness of a poor man. A well-dressed rich $\operatorname{man}^{41}$ and an unattractive ${ }^{42}$ poor man pay simultaneous visits to a Christian meeting, and this creates a problem. The congregation has to deal with both. They should not have failed to offer both men an appropriate welcome. The rich man is dressed in all the marks of a man of luxury and pretension. ${ }^{43}$ His self-presentation invites public admiration and special honour. His nonverbal communication probably proposes a willingness to bestow favours on those who please him. He suggests preferential treatment and demands a very high price for their allegiance (cf. 4:13). The visit of the rich man becomes a test of Christian faith.

In stark contrast, the other man is referred to as 'poor'; his clothes are shabby and grimy. The term James uses to refer to this second visitor denotes the economically poor ${ }^{44}$ and therefore impoverished, rather than those from the lowest

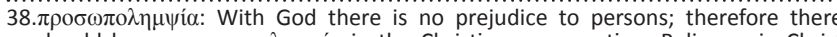
should be no $\pi \rho \circ \sigma \omega \pi \mathrm{o} \lambda \eta \mu \psi i \alpha$ in the Christian congregation. Believers in Chris cannot show partiality; James 2:1 (Lohse 1976:[6]780).

39.There is a strong affinity between what James wrote in this passage and Leviticus 19:15. The command in that verse says: 'Do not pervert justice; do not show partiality to the poor or favoritism to the great, but judge your neighbor fairly.' Respect for the whole spectrum of God's people, particularly toward the defenseless and needy, runs throughout Leviticus 19 . Whenever judgements are defenseless and needy, runs throughout Leviticus 19. Whenever judgements are made, based on selfish gain rather than on true need or on the truth about wrongful act, justice is perverted. Neglect of orphans and widows (cf. James 1:27) and the poor visitor in church (cf. 2:2) are good examples of Christian neglect; that is, they are sins of omission and injustice. See Johnson (1982:391-401) who points
out this connection in the greatest detail.

40.McKnight (2011:186) is of the opinion that this is not a historical description of the real circumstances, but rather a rhetorical device. He compares it with Jesus' parable of the rich man and Lazarus.

41.According to Stegemann \& Stegemann (1999:79), wealthy people in antiquity stood out from the rest of the populace through their sumptuous eating habits as well as their clothing. Cf. Luke 7:25; 16:19-31; 23:11; Acts 10:30. See also Stegemann \& Stegemann (1999:78-80)

42.The poor man is free of any jewellery and has only dirty clothing ( $\rho v \pi \alpha \rho \tilde{\alpha}, 2: 2$ ) (McKnight 2011:185)

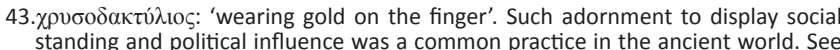
Luke 15:22; also cf. Noack (1964:10-25).

44.Cf. Ward (1969:87-97). social class. The imperative statement 'sit under my footstool' may be taken to mean 'sit on the floor by my footstool', or more generally 'sit here on the floor by my feet'. This refers to a sharp contrast in treatment: one person is referred to a high and comfortable seat; and the other is abruptly told to squat on the floor. ${ }^{45}$ The indication to sit at 'my feet' shows that the poor visitor is also treated worse than the host himself. The host at least has a seat for himself (Loh \& Hatton 1997:64).

Painfully, the congregation becomes a gathering for the oppression of the poor. The poor man is humiliated and devalued.

\section{Envy and selfishness}

Who is wise and understanding among you? Show by your good life that your works are done with gentleness born of wisdom.

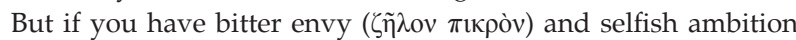

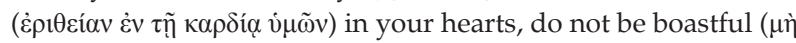
$\kappa \alpha \tau \alpha \kappa \alpha \nu \chi \tilde{\alpha} \sigma \theta \varepsilon)$ and false to the truth. Such wisdom does not come down from above, but is earthly, unspiritual, devilish. For where

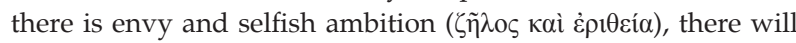
also be disorder and wickedness of every kind. ${ }^{46}$ (Ja 3:13-16)

This text relates to the harmful deeds of the rich (employers) committed against the poor (employees) as spelled out by James and as discussed earlier in this research under the subheadings Fraud against the poor and Harm done by the employer. It explains how selfish desires are at the root of all these transgressions on the part of the rich. According to James, the two most fundamental attitudes behind these destructive deeds of the rich are 'envy' and 'selfish ambition'. In this text, envy, like jealousy, places an extreme focus on another person's possessions and relationships. ${ }^{47}$ This desire to imitate and exceed another, even if it might mean stealing from the other, destroys relationships. James commands them, if these harmful attitudes were present in the hearts of his readers, to stop boasting. ${ }^{48}$ If they do not stop, they would be denying ${ }^{49}$ the truth they believe in (Richardson 2001:164).

According to James, these selfish desires are born of wisdom that 'does not come down from above' (3:15). This is another

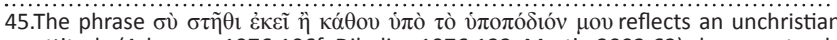
attitude (Adamson 1976:106f; Dibelius 1976:132; Martin 2002:62) shown not only towards the poor man, but also the rich.

46. Also 4:1-3: 'Those conflicts and disputes among you, where do they come from? Do they not come from your cravings that are at war within you? You want something and do not have it; so you commit murder. And you covet something and cannot obtain it; so you engage in disputes and conflicts. You do not have, because you do not ask. You ask and do not receive, because you ask wrongly, in order to spend what you get on your pleasures.'

47. $\zeta \tilde{\eta} \lambda$ ov: as a human emotion expressing active enthusiasm, ardent affection, keen interest zeal, ardor, jealousy (Friberg, Friberg \& Miller 2000:185); zeal can be used in a good sense or an evil sense, as in James, to refer to envy, jealousy, anger or 'fiery wrath' (Zodhiates 2000:G2205); or 'be jealous, be envious' (Swanson 1997:2420,

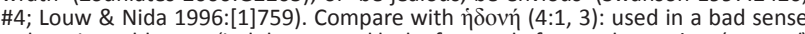
as here it could mean 'indulgence and lack of control of natural appetites (sensual) pleasure, passion, lust' (Friberg, Friberg \& Miller 2000:189). According to Louw \& Nida (1996:[1]129), to 'set one's heart on something that belongs to someone else - 'to covet' ... 'to be envious' or 'to be jealous'; (1996:[1]759): 'to experience strong envy and resentment against someone - 'to be jealous, to be envious.'

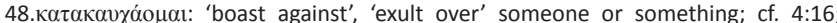
Jeremiah 27:11; Zechariah 10:12; Romans 11:18.

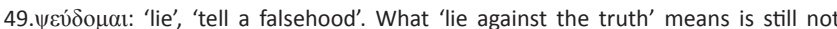
obvious; cf. Joshua 24:27; Psalm 17:45; Proverbs 14:5; Jeremiah 5:12; Matthew 5:11; Acts 5:3-4 (they 'lied to the Holy Spirit'); Romans 9:1; Galatians 1:20; Colossians 3:9; 1 Timothy 2:7; Hebrew 6:18; 1 John 1:6; Revelations 3:9; Philo Leg. All. 3.124; T. Jos 13.9; 1 Clem 27.2; Herm. Man. 3.2. 
'wisdom' that is 'earthly, unspiritual ${ }^{50}$ and devilish'. This 'wisdom' is self-centred and oriented towards personal gain, and it stands behind the boasting and self-deception so frequently condemned in the letter. This particular wisdom corresponds to a particular way of life. James speaks of the rich man's way of life that quickly passes away (1:11) and the corruption of one's whole way of life by corrupt speech (3:6). As the earthliness of this wisdom expresses a way of life that is centred upon physical needs and urges, the unspiritualness of this wisdom further expresses a way of life centred upon the dictates of the selfish mind and heart. This 'wisdom' is a law unto itself, approving and disapproving in an arrogant and autonomous way (Richardson 2001:166).

\section{Boast in arrogance}

Come now, you who say, 'Today or tomorrow we will go to such and such a town and spend a year there, doing business

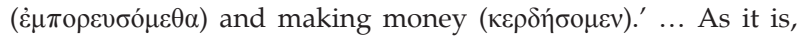

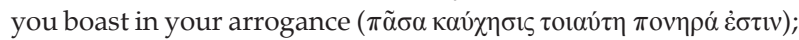
all such boasting is evil. (Ja 4:13-16)

This passage is aimed at the arrogant merchant. The skilful use of the repetitive we will go ... and stay ... and make a profit and the mention of the year's stay both suggest deliberate and calculated arrogance (Adamson 1976:129). Trading and commercial activities were limited to the native aristocracy of large land owners who, according to Rostovtzeff (1971:1, 270), were not only 'rulers of the land and leaders in its religious life, but capitalists and merchants ${ }^{51}$ on a big scale, who sometimes add to their wealth by daring speculations'.

What James writes in 4:13 is based on the socioeconomic realities of his milieu. His cry is directed at the merchants throughout Syro-Palestine for whom the accumulation of wealth was an ultimate goal. This, according to MaynardReid (1987:77), made the availability of raw material and the ease with which the wealthy entrepreneurs could reach their destination and then dispose of their goods more understandable because of the arrogant assertion: 'Today or tomorrow we will go into such a town and spend a year there and trade and get gain. ${ }^{\prime 52}$ The expression 'to gain' may be rendered as 'to make money' or 'to make a profit' (Loh \& Hatton 1997:159). This attitude explains the negative conduct of the wealthy entrepreneurs towards the poor.

Instead of confessing their dependence on the will of God, the arrogance $\mathrm{e}^{53}$ of the wealthy erupt and overflow with bragging. More precisely, to brag here means to manifest the pretence of the self-creation and sole causation of one's own well-being. ${ }^{54}$

50.40xikóc: 'pertaining to the soul or life', consistently used in the New Testament for earthly, material existence as against divine reality (cf. 1 Cor 2:14; 15:44); thus the physical forces of the body and mind.

51.Cf. my elaborated discussion of these 'merchants' in my publication in Van der Merwe (2009:89-108).

52.See Maynard-Reid (1987:77) on his references to Jewish and non-Jewish literature.

53. $\dot{\alpha} \lambda \alpha \zeta o v \varepsilon i ́ \alpha:$ characterised by presumption in word or action arrogance, pretension (Friberg, Friberg \& Miller 2000:42); bragging (of one's own control of destiny or future events) (Swanson 1997:224); also cf. Wis 5:8; 4 Macc 1:25-26; 2.15; 8.19; $T$. Jos 17.8; Philo (1995b) Virt. 162ff.; Josephus Ant. 6.179; 1 Clem 21.5; 13.1; 16.2; 35.5; Herm. Man. 6.2.5.

54.The condemnation of pretense is similar in 1 John 2:16 (cf. Job 28:8; $\operatorname{Pr} 21: 24$; Hab 2:5; Rm 1:30; $2 \mathrm{Tm} \mathrm{3:2)} \mathrm{within} \mathrm{the} \mathrm{context} \mathrm{of} \mathrm{loving} \mathrm{the} \mathrm{world} \mathrm{(cf.} \mathrm{Jas} \mathrm{4:4)} \mathrm{rather}$ than God and taking pride in one's possessions.
James now identifies arrogance as the cause of the failure to take God into account in making plans (Loh \& Hatton 1997:162; also Martin 2002:168). Extra-biblical literature ${ }^{55}$ is also filled with condemnations of this presumptive attitude, so common in the world.

James wants the believers to have absolutely nothing to do with boasting and arrogance. In such statements, there is no willingness to yield to God's will. Thus, James is quite strict. Not only does he prohibit boasting about possessions, but believers should not even boast about their plans for the future. Boasting sets human beings above God and robs him of the sovereignty that belongs to him alone (Loh \& Hatton 1997:163).

\section{Positive attitudes}

In this subsection, it will be pointed out how James urges the poor, in difficult situations, to try to do two things to

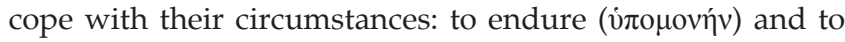
be patient ( $\mu \alpha \kappa \rho \theta \theta \nu \mu \eta ́ \sigma \alpha \tau \varepsilon)$. These two attitudes complement one another.

\section{Manage your trial of wealth or poverty with perseverance}

'My brothers and sisters, whenever you face trials ( $\pi \varepsilon \iota \rho \alpha \sigma \mu o i s)$ of any kind, consider it nothing but joy, because you know

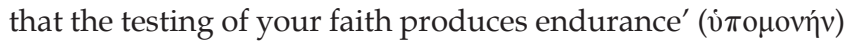
(Ja1:2-8, 12-19). The passage about the lowly boasting of the poor and the high boasting of the rich (1:9-11) stands in literary context between two passages regarding trials and temptation. ${ }^{56}$ The word 'trial', however, also means 'testing' $\left(\delta\right.$ oкí $\left.\mathrm{L}_{\mathrm{o}} \mathrm{v}^{57}\right)$, referring to outward troubles and difficulties. Such testing causes the person being tested to emerge stronger and better in loyalty and in faith. Whilst not ruling out the possibility of financial suffering and persecution, the context appears to indicate that the noun, trials, here probably means nothing more than daily troubles of some sort. ${ }^{58}$ Both the rich and the poor are tested in their respective situations. For the rich, this can include 'to convert their money to help the poor' and for the poor 'to endure in their poverty'. ${ }^{59}$

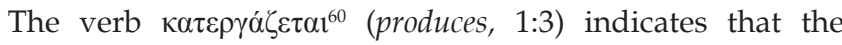
'faith' that can withstand 'trials' is bound to 'produce' a positive result, namely the ability to endure. ${ }^{61}$ Steadfastness

55.See Herm. Vis. 2.3.1; Man. 3.3; Sim. 6.3.5.

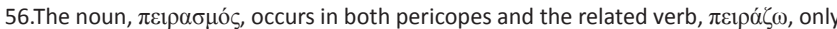
in 1:12-18.

57.Danker (2000:256) defines this as 'the process or means of determining the genuineness of something, testing, means of testing'.

58.James refers to 'trials of many kinds' which could have had a multitude of afflictions in view: conflicts from opponents, doubts, fears, and tribulations. These trials are mostly external in comparison with those discussed later in the chapter (Richardson 2001:58). See also MacArthur (1998:39) for his connection of this reference to trials with poverty.

59.This deduction is due to the immediate context where the following pericope $(1: 9-11)$ deals with the issue of 'poverty and riches' and is also due to the multiple occurrences of this theme throughout the letter (see Richardson 2001:59).

60.According to Friberg, Friberg and Miller (2000:[4]224), it carries the meaning of 'as achieving an effect whether in a good sense' or 'bad sense' ( $\mathrm{Rm} 7: 8$ ).

61.In every trial, Christian believers should see their preparation for greater things God has planned for them (cf. Jdt 8:25; Lk 2:10; Mt 5:10-15; 1 Pt 4:12-14; 1 Th 3:3; Ac5:41) (Richardson 2001:59). 
( In Greek, the verb steadfastness, rendered 'endurance', does not mean a passive submission to circumstances. It is rather an active quality that will enable the poor to persevere steadfastly through the most difficult and trying circumstances (Loh \& Hatton 1997:13). James urges the poor towards such perseverance. The knowledge of this truth is the cause of their 'pure joy', which rests upon the future revelation of God and the reversal of their circumstances (Ml 3:17-18; Richardson 2001:58).

\section{Remain patient during difficult circumstances}

For James, the second attitude to be practiced by the poor in difficult circumstances is to remain patient. Poor people must be patient about what God is going to do:

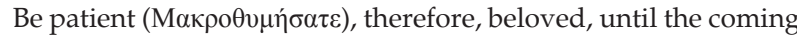
of the Lord. The farmer waits for the precious crop from the earth, being patient ( $\mu \alpha \kappa \rho о \theta \nu \mu \tilde{\omega} v)$ with it until it receives the early and the late rains. You also must be patient. Strengthen your hearts, for the coming of the Lord is near. ... Indeed we call blessed

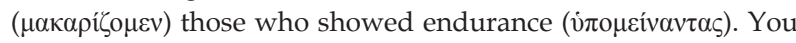

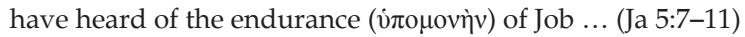

With this pericope, James starts the closure of his letter, returning to the initial theme of trials in the Christian life. He exhorts his Christian 'brothers ${ }^{\prime 63}$ ( $\dot{\alpha} \delta \varepsilon \lambda \varphi$ oí$)$ to be patient in the midst of suffering that is caused by injustices done to them. Patience is the major theme of this pericope (see also Martin 2002:190) ${ }^{64}$ The conjunction particle oṽv, 'then' or 'therefore', closely connects the call to patient waiting to the previous section by reminding the listeners of God's opposition to the unjust rich. The response to the suffering Christians is given in the light of the judgement of the rich. They have forgotten that God is the judge (as in 4:11-12) whose coming ( $\pi \alpha \rho$ ov $\sigma^{\alpha} \alpha$ ) is close at hand (Martin 2002:187). ${ }^{65}$ Therefore, James calls on

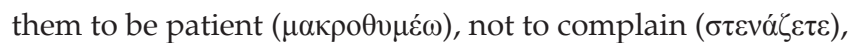

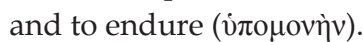

The verb 'patient' ( $\left.\mu \alpha \kappa \rho о \theta v \mu \eta \dot{\sigma \alpha} \alpha \varepsilon^{66}\right)$ is used here in 3 of its 10 occurrences in the New Testament to carry emphasis. Patience has already been indicated as a cardinal virtue produced by testing $(1: 2-4,12)$, although in that case the noun, vं places the two nouns in parallel. Also in this pericope James combines these two nouns ( $\mu \alpha \kappa \rho \circ \theta v \mu \eta \dot{\sigma \alpha \tau \varepsilon, ~ v ं \pi о \mu о v \eta े v) . ~ W h a t ~}$

62.'endurance, perseverance, patience' (see also Lk 8:15; $21: 19 ; \mathrm{Rm} 2: 7 ; 5: 3 ; 8: 25$ 15:4; 2 Cor 6:4; $1 \mathrm{Tm}$ 6:11; 2 Tm 3:10; Heb 12:1. Jas 1:3; 5:11; 2 Pt 1:6; Rv 2:2, 19 GI 5:23) (Swanson 1997:DBLG 5705).

63. Note the radical shift in tone from 'you rich' in verse 1. I disagree with arguments that place the rich outside the Christian community simply because they are not amongst James's addressees.

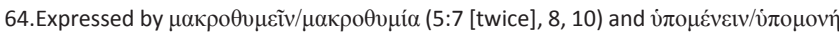
('stand firm,' 5:11 [2x]).

65.See Martin (2002:187ff) for a good discussion on this eschatological motif.

66. $\mu \alpha \kappa \rho \circ \theta \nu \mu \tilde{v: ~ ' t o ~ e n d u r e ~ p a t i e n t l y ~ a s ~ o p p o s e d ~ t o ~ l o s i n g ~ f a i t h ~ o r ~ g i v i n g ~ u p ' ~}$ (Zodhiates 2000:G3114); 'to demonstrate patience despite difficulties - 'to be patient, to remain patient, to wait patiently" (Louw \& Nida 1996:[1]306). Also in v. 8; cf. Hebrew 6:15 and the sense of absolute dependence upon God; Job 7:16; Sir 2:4; T. Jos. 2.7). This can refer to God's forbearing ways ( $\operatorname{Pr} 19: 11)$. Thus it can be Christian virtue that imitates one of the attributes of God; cf. Matthew 18:26, 29; 1 Thessalonians 5:14; 2 Peter 3:9; Sir 18.11; 29.8; 1 Clem 49.5. According to Loh \& Hatton (1997:180), the verb here means a 'patient waiting, an ability to take and Hatton (1997:180), the verb here means a 'patien
absorb difficult and irritating things or people'. is clear in this pericope is that James is calling on Christians not to take the judgement of the wicked (rich) into their own hands but to wait for God to avenge their oppressors. At the same time, they are called upon not to compromise their faith; both giving in to the world and attacking the world are wrong. Christian believers need self-control. Christians need to put aside all thoughts of retaliation and revenge (Lea 1999:354). ${ }^{67}$

Waiting for God to act can, however, become a long process (cf. $2 \mathrm{Pt}$ 3). Therefore, James gives his readers an example of such patience from everyday life. James uses the example of a farmer who must labour without knowing what the weather will bring or the degree of abundance of the precious crops. He must exercise patience no matter how hungry he is ( $\mu \alpha \kappa \rho \theta v \mu \tilde{\omega} v)$, for he waits with a view toward the coming harvest ( $\left.\dot{\varepsilon} \pi^{\prime} \alpha \nu \tau \tilde{\omega}\right)$. This patience must last 'until he receives the early and late rain'. Just as the farmer can do nothing to speed up the rainfall, and subsequently the harvest, but to wait for the appointed time by God, so the Christian community must be patient even in the midst of abuse and suffering. The sense of patience in this case includes waiting and endurance until the Lord takes action on their behalf. 'The point then is not the length of time for waiting but the need to remain steady during that time' (Loh \& Hatton 1997:181).

\section{Antithetical attitudes}

'Let the brother who is lowly (ó $\alpha \delta \varepsilon \lambda$ pò

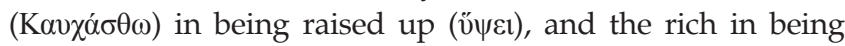
brought low ...' (Ja 1:9-11).That the question of the poor person's situation is high on James' agenda is evident from the fact that it appears so early in the document. ${ }^{68}$ Even the conduct of the rich is a matter of great concern for him. In 1:9-11, James

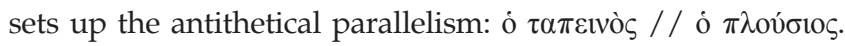
The primary meaning for $\dot{o} \pi \lambda$ ov́бıৎ is 'the rich' whilst for $\dot{o}$ $\tau \alpha \pi \varepsilon i v o ̀$ it is 'lowly, poor, undistinguished' ${ }^{\prime 69}$ or 'pertaining to having low and humble status' (Louw \& Nida 1996:[1]739). The word 'lowly' should be understood in contrast to 'the rich' in verse 10. James wants it to mean 'poor' but poor both economically and socially, referring to someone who lacks material goods and at the same time is socially despised and oppressed (Loh \& Hatton 1997:22). Hence, there seems to be no question that James is dealing with the antithesis of the poor and rich in these verses. ${ }^{70}$

Here in James, the poor are called upon to exalt themselves because God has chosen them for an exalted position (cf. 2:5; Mt 5:3,5). These Christians must overlook the present

67.See Hebrew 6:12, 15; Hebrew 10:32-39; 12:1ff.; 1 Peter 4:12-19; Romans 12:9-21; Revelation 13:10; 14:12; even in Revelation the $\dot{\alpha}$ í $\omega v$ never strike back; cf. also the work done by Horst 1978:[4]374-387; Hauck 1978:[4]581-588; Falkenroth \& Brown 1976:[2]768-776. But Lea (1999:356) correctly points out that 'To call for patience and perseverance does not rule out protesting a wrong.'

68.See Maynard-Reid (1987:38-47) for a thorough discussion on the relationship between 1:9-11 and 1:2-8 to gauge the intensity of the author's interest in this topic.

69.According to Friberg, Friberg and Miller (2000:374), it refers to 'persons, of trivial power or significance lowly, poor, undistinguished' people. In 4:6, it refers to humble people. Zodhiates (2000:G5011) understands it as 'Low, not high, particularly of attitude and social positions. Of condition or lot, meaning humble, poor, of low degree'.

70.Cf. 1 Enoch 108.1-15. 
circumstances $^{71}$ in which it is the rich who boast (as in 4:16 and Ps. 49[48]:7). They must see life from an eschatological perspective in which the one who really has the exalted position and who is really rich is the Christian, the poor person (Davids 1982:76; also cf. MacArthur 1998:39). The poor and lowly are encouraged to see their glory in the rich heavenly reward that has been promised to them. That salvation includes the reversal of the status of poor and rich, of wise and foolish, of strong and weak, and of noble and despised (cf. 2:5) (Richardson 2001:70). So, this poverty ends up in a double benefit. It encourages firstly humility and secondly faith in God (Richardson 2001:71).

Although the wealthy may seem powerful now, God will reduce their power in the end unless they humble themselves. Here James refers to a reversal of status (Davids 1982:75). The rich person is called with a sharp ironic twist to understand the humiliation with which he may have to live. He exists like the rich fool (Lk 12:13-21) in luxury in this age only to discover the true system of values in the coming age. There may also be the suggestion that, if the rich really embraced humiliation, they would really have something to boast about. Thus James works with the schema of humiliationexaltation (and vice versa).

In the immediate literary context this statement has both a physical and an emotional connotation. The physical connotation comes to the fore when it is interpreted with the parallelism in connection with o $\pi \lambda$ ov́ $\sigma 10 \varsigma$ (the rich). The emotional meaning overrides the physical meaning when

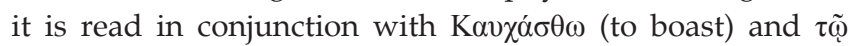

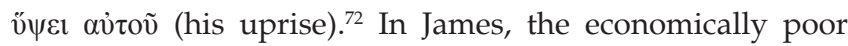
and oppressed should not be separated from the pious. For James, a close relationship exists between being humble in status and being humble in spirit, at least within the context of genuine faith, which he assumes. Low social standing is bad on many levels for those who are poor. James encourages those of low standing as Christian believers to boast or to 'take pride' in their coming exaltation. ${ }^{73}$

Verses 10-11 focus on the second part of the antithesis, and James dwells at length on this particular aspect throughout the rest of the letter. He emphasises the downfall of the rich and as such sets up a contrast between the poor and the rich. The poor will be exalted and thus can truly boast (Ropes 1961:145). The rich will be brought low ( $\tau \tilde{n} \tau \alpha \pi \varepsilon เ v \omega ́ \sigma \varepsilon \imath)$, not necessarily by the loss of property and social standing ${ }^{74}$ and will 'fade away' (v. 11).

71.Cf. Philo's (1995b:5) De Virtutibus.

72.See Maynard-Reid (1987:40ff) for a discussion on the meaning of ó $\tau \alpha \pi \varepsilon$ เvò

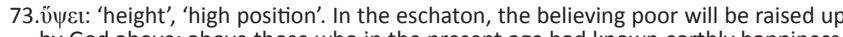
by God above; above those who in the present age had known earthly happiness. For the socioeconomic interpretation, which is helpful but pays too little regard to the churchly context of the epistle, cf. Maynard-Reid (1987:40-41). For a bette understanding of 'humility', cf. Louw \& Nida (1996:[1]748). Here the poor are indeed humble because they are humbled by the condition of their lives and by
their being neglected by the wealthy.

74.Ropes (1961:147f) suggests that the bringing low is through the loss of possessions. This may be by reason of his profession.

\section{Section conclusion}

In this section, two negative attitudes (external judgement and arrogance) which occur amongst the rich have been pointed out. All the destructive acts converge in the selfishness of the rich which is, according to James, the heartbeat of sin in a person's life (3:16). Over and against this, the poor are called upon to endure and to be patient. These two attitudes complement one another to strengthen the poor in order to cope with their circumstances. Patience is needed in order to endure.

The research will now turn to James's encouragement of the poor.

\section{Consequences for the rich}

From the above discussion, it becomes evident how much James was aware of the irregularities and discrimination that occurred in the early church. To encourage the poor, he connects the fate of the unjust rich to ending up with nothing. Twice, in the beginning (1:10-11) and at the end (5:1-6) of this epistle, James refers to the consequences of the rich. The positions of these references are like using inverted commas to emphasise that any unfair act by the rich will in the end lead to their decay (5:1-6); they will 'wither away' (1:10-11).

\section{The rich will wither away}

Let the believer who is lowly boast in being raised up, and the rich in being brought low, because the rich will disappear $\left(\pi \alpha \rho \varepsilon \lambda \varepsilon v \sigma_{\varepsilon \tau \alpha l}\right)^{75}$ like a flower in the field. For the sun rises with its scorching heat and withers the field; its flower falls, and its beauty perishes. It is the same way with the rich; in the midst of a busy life, they will wither away ( $\mu \alpha \rho \alpha v \theta \dot{j} \sigma \varepsilon \tau \alpha$ l). (Ja 1:9-11)

In these three verses, James uses two striking words

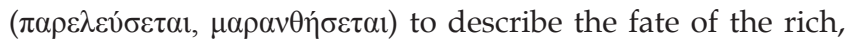
due to their excessive acts towards the poor and their busy life of generating more riches. Whereas the poor are destined for eternal joy in the great reversal, the rich are doomed to pass away ( $\pi \alpha \rho \varepsilon \lambda \varepsilon v ́ \sigma \varepsilon \tau \alpha l)$. This carries with it an eschatological nuance to be repeated in 5:5 (Martin 2002:26). In the first instance, the rich are compared to a wild flower, a familiar Old Testament image of fragility. ${ }^{76}$ As the exaltation of the poor believer will appear like life from death, the lowering of the rich ${ }^{77}$ to a place amongst the least rewarded will be its own kind of manifestation. This metaphor of the falling flower relates to an apocalyptic vision of dying creatures under the judgement of God (Richardson 2001:73).

The second verb, $\mu \alpha \rho \alpha v \theta \dot{\eta} \sigma \varepsilon \tau \alpha$, denotes the 'withering away' of flowers and also the death of persons (Danker 2000:616).

75. Metaphorically, it means to pass away, to perish (cf. Mt 5:18; $24: 34,35 ; \mathrm{Mk} 13: 30$, 31; Lk 16:17; 21:32, 33; 2 Cor 5:17; Ja 1:10; 2 Pt 3:10; Rv 21:1; Sept.: Ps 37:36). Cf. also Zodhiates 2000:G3928; Friberg, Friberg and Miller 2000:300; Swanson 1997:4216, \#5.

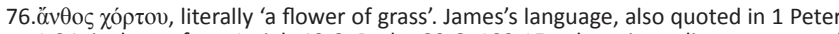
$1: 24$, is drawn from Isaiah 40:6; Psalm 89:6; 103:15, where it applies to temporal life in general. The suggested greater losses of the rich intensify the power of the image.

77.There is disagreement on whether the 'rich' refers to a Christian or not (Martin 2002:25). See Loh \& Hattan 1997:23-4 for the different arguments. A neutral translation and reference have been opted for. 
James inexorably connects the fate of the flower to the fate of the rich person. Both can be flourishing one day and gone the next. God's eschatological judgement will cause the unjustly rich to perish. Dibelius (1976:85) points out that the transitory nature of humanity is often described with the aid of the image of grass and vegetation. Thus, the rich man's 'humiliation' is the judgement he suffers (v. 10) (Martin 2002:27f). The process of 'fad[ing] away'78 is harsh. The Middle Eastern sun 'rises', and its heat scorches ${ }^{79}$ the flowers, quickly causing their beauty to fade. They become mere dried-up grass with which to kindle fires. Their appearance is gone forever under the sun. The beauty of the flower is related to the beauty of a wealthy man's busy life. All the selfish desires and effort to maintain success and influence are soon lost. From the text, it is quite clear that the rich are also made busy by their wealth. James tries to portray the drive of the wealthy. He is much like the hard-working rich farmer who is told in his own apocalyptic moment that he is utterly poor in the eyes of God and his life is at its end (Lk 12:15-21)..$^{80}$

The rich man should beware, according to James, because he 'will fade away's1 together with all his undertakings. In the very movement and manner (v. 8) of displaying the beauty of a wealthy life, all will be lost (cf. 4:13-16). ${ }^{82}$ This is how things will develop for the rich (cf. v. 24). Perishability and loss rule over all of life. Consequently, the losses of the wealthy will be greater. The biblical meaning of this loss is reflected in 1 Corinthians 3:12-13. Here Paul is saying that a believer can build a life of service upon the perishables of worldly value, but in the end all of it will be lost. Thus the life of the rich and their wealth together will fade away (Richardson 2001:70).

\section{The decay of the rich (James 5:1-6)}

In this pericope, James concludes his final attack on the rich:

Come now, you rich people, weep and wail for the miseries that are coming to you. Your riches have rotted, and your clothes are moth-eaten. Your gold and silver have rusted, and their rust will be evidence against you, and it will eat your flesh like fire (Ja 5:1-3).

From a denunciation of a spirit of arrogant financial scheming in the beginning of the letter, James turns to a spirit even more intolerable - a spirit which is selfish, tyrannical, and oppressive - at the end of the letter. The cries of the oppressed, instigated by the oppressive actions of the rich,

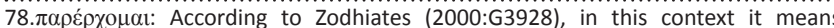
'Metaphorically, to pass away, perish. Used in an absolute sense in a general way cf. Matthew 5:18; 24:34, 35; Mark 13:30, 31; Luke 16:17; 21:32, 33; 2 Corinthians cf. Matthew 5:18; 24:34, 35; Mark 13:30, 31; Luke 16:17; 21:32, 33; 2 Corinthians
5:17; James 1:10; 2 Peter 3:10; Revelation 21:1; Sept.: Psalm 37:36.' Another word

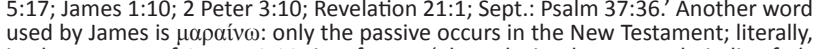
used by James is $\mu \alpha \rho \alpha i v \omega$ : only the passive occurs in the New Testament; literally,
in the context of James 1:11, it refers to 'plants losing beauty and vitality fade away, dry up, wither; figuratively, of persons waste away, end up with nothing, lose out' (Friberg, Friberg \& Miller 2000:253)

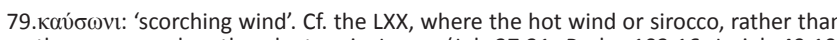
the sun, scorches the plant as in James (Job 27:21; Psalm 103:16; Isaiah 49:10 Jeremiah 18:17; Ezekiel 17:10; Hosea 12:1; Jonah 4:8); and also Jesus' teaching (Mt 20:12; Lk 12:55).

80.Death can come at any time. At the same moment, this person stands at their own personal end (eschaton) before the judgement of God. Although James had the universal judgement in mind in the whole of his letter, personal eschatology may have been part of his teaching here.

81. Here is the only place where the verb $\mu \alpha \rho \alpha i v \omega$ ('fade, waste, disappear') occurs in the New Testament. Cf. 1 Peter 1:4; Herm. Sim. 9.23.2.

82.Cf. 1 Enoch 97.5-10. have reached the ears of the 'Lord of hosts'. James presents the rich here as committing two main crimes: (1) luxurious living 83 and (2) oppression. ${ }^{84}$

Again James starts with 'A $\gamma \varepsilon$ võv, as in 4:13. This repetition of the cry heightens to an even greater degree James's denunciation of the rich, and his attitude toward them peaks in the harsh language of the passage. This high rhetorical language of the coming eschatological fate ${ }^{85}$ of the rich is in the style of the Old Testament prophets (which parallels Jewish apocalyptic writing and is patterned on the Old Testament's 'day of Yahweh' theme, e.g. Am 5; Zeph 1:11-15). As in the Old Testament, the address is not intended to influence the rich. They are no more part of the listening congregation than the nations and peoples addressed in Isaiah 34:1. These explosive expressions are neither a call to repentance nor counsel to them concerning the right use of wealth (cf. Martin 2002:173). These words actually describe the misery of the rich that is impending and are probably intended more as a comfort and consolation to the oppressed who could find relief that ultimate judgement would come upon their oppressors (Dibelius 1976:231; see also Martin 2002:173). It is to the economically rich persons who oppress the poor that James offers only pronouncements of judgement.

Even though the rich may have given thanks to God for their successes, their praises would be a facade if they neglected the needs of poor labourers. The vicious connection between idolatry, mercilessness and murder becomes part of the guiding logic of James as he severely warns his audience. ${ }^{86}$ God, who 'opposes the proud' (4:6) here, does so by assassinating them because, as seen in 2:13, 'judgment without mercy will be shown to anyone who has not been merciful'.

\section{Section conclusion}

In this section, it was discussed how James asserts what is going to happen to the rich. In two passages, James uses different though related vocabulary to describe how the rich is going to disappear. By using metaphors, he says much more and emphasises how the rich will come to their end.

\section{Exhortations to help the poor}

This subsection points out how the early church was called upon to stretch out a hand of support to those in need. Such conduct is referred to by James as an essential part of practising religion. Faith without demonstrable actions is useless. In 1:27, James identifies some specific groups of the poor, and in 2:15f, he refers to them in general.

83.It seems as if James was thinking of the existing situation around him. The possession of much clothing was a customary sign of wealth, and the stock of clothing was popular.

84.A literal interpretation would restrict James's reference to those possessions that are capable of 'rotting'. But the occurrences of this verb in the LXX (it does not occur elsewhere in the New Testament) show that it can be applied metaphorically to anything that is transitory. See, for example, 'every work decays and ceases to to anything that is transitory. See, for example, 'every work decays and ceases to 19:20; 33:21; 40:12; Ps 37:6; Ezk 17:9; Ep. Jer. 1:71) (Moo 2000:213).

85.See Richardson 2001:208; Martin 2002:173 and Moo 2000:215.

86.Cf. Deuteronomy 12:30-31; Isaiah 1:21-23; Jeremiah 2:27, 34; Ezekiel 16:49, 52; Amos 5:4-6; Habakuk 1:16. 


\section{Take care of orphans and widows}

Religion that is pure and undefiled before God, the Father, is

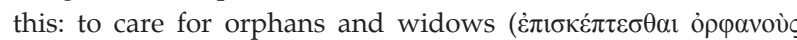

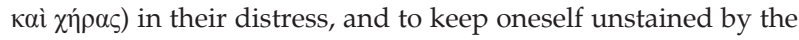
world. (Ja 1:27)

Orphans ${ }^{87}$ and widows are joined because they represent two social classes open to exploitation and $\theta \lambda \tilde{i} \psi 1 \varsigma$ ('affliction') in Israel, as in Isaiah 1:10-17; Isaiah 58:6-7; Zechariah 7:10; Mark 12:40; Luke 18:2-8 (Martin 2002:52). They were regarded as outcasts in the ancient world. Not to give aid to these poor ones turns out to be only the beginning of the problem. The rich later come under the charge of being active oppressors of the poor (cf. 5:1-6; Barn 20.2). Just as God comes to the aid of those in need, those who practice true religion should 'look after' ${ }^{\prime 88}$ orphans and widows, those most vulnerable members of the church and society. ${ }^{89}$ Orphans and widows are the objects of repeated appeals to administer to the needy and helpless..$^{90}$ These exemplify the poor to whom God shows special favour (cf. 2:1-7) against the natural human preference for the wealthy. The poor are necessarily of chief concern to the church because they live under such hard labour. ${ }^{91}$ The unending tribulation of grinding poverty must move believers and their churches to assist the poor in every way: economically, legally and politically. Proper Christian aid and defence of the poor can shape their social and economic conditions in a dramatic way, and often for the good of all (Richardson 2001:101).

James connects any support of these two groups with the true nature of religion.

\section{Help the poor where necessary}

If a brother or sister is naked and lacks daily food, and one of you says to them, 'Go in peace; keep warm and eat your fill', and yet

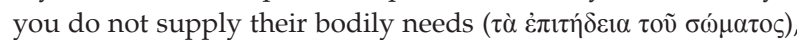
what is the good of that? (Ja 2:15-16).

In the pericope, 2:14-25, James shifts the focus of his address from the indirect interlocutors to his readers: 'If one of you says ... '. This redirection of the referent makes James's message all the more confrontational. Verses 15-16 offer a parable in miniature. ${ }^{92}$ Verse 15 pictures people who need clothes and food. These believers desperately need the necessities of life! The context for the encounter of the poor is not limited to a particular assembly of Christians. The reference here to the

87.McKnight (2011:170) points out that 'recent study of papyri has shown that to be called an orphan requires only that one has lost one parent and not both'. Loh \& Hatton (1997:55) confirm this.

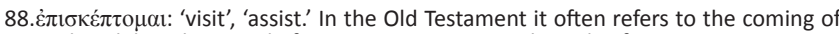
God to deliver his people from a crisis or visiting the sick; cf. Genesis 21:1; 50:24 Exodus 3:16; 4:31; Joshua 8:10; Ruth 1:6; 1 Samuel 2:21; Zechariah 10:3; Matthew 25:36, 43; Luke 1:68, 78; Acts 7:23; 15:14; Sir 7.35.

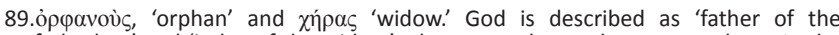
fatherless' and 'judge of the widow' who curses those who oppress them. In the early church elders were charged to act as the fathers of orphans; cf. Exodus 22:22; Deuteronomy 26:19; Job 31:16f.; Psalm 68:5; Luke 20:47; Sir 4:10; Herm. Man. 8.10 .

90.Cf. Exodus 22:20-21; Leviticus 19:9-10; Deuteronomy 10:17-19; 24:17-18; Proverbs 19:17; Isaiah 3:5; Jeremiah 22:3; Amos 2:6-8; Hosea 12:8-9; Malachi 3:5.

91. $\theta \lambda$ ĩ 1 c: 'distress' in the combined sense of grief and want; cf. Exodus 4:31; Deuteronomy 4:29; Matthew 13:21; 24:9; Acts 7:10; Romans 8:35.

92.Adamson 1976:122; Dibelius 1976:152f; Lea 1999:286; Moo 2000:103. brother or sister who is lacking food and clothing ${ }^{93}$ is much like the example of the poor man who visits the local church $(2: 2-3)$. Within the fellowship of believers there are always those who lack the necessities of daily life (Martin 2002:84). These members of the church are easily overlooked because of their constant neediness. What is at stake here is what has to be done for these poor people (Richardson 2001:130). The conduct James has in mind for his readers is largely akin to what is at issue in John's first epistle:

If anyone has material possessions and sees his brother in need but has no pity on him, how can the love of God be in him? Dear children, let us not love with words or tongue but with actions and in truth. (1 Jn 3:17-18)

The statement, 'Go, I wish you well' or more literally, 'Go in peace $^{\prime 94}$ in the ancient world was honest only when it accompanied some demonstrative act such as giving a gift or alms (Richardson 2001:130). Also evident here is the close connection between mercy (pity) and helpful actions for the poor.

\section{Section conclusion}

This section described how James twice called on the early Christian church to take care of the poor. In the first passage, he refers to two groups of poor people, namely widows and orphans. In the second passage, he uses a parable to describe how it should be done.

The content of this research was presented in terms of a development from the negative conduct and attitudes of the rich towards the poor to a positive encouragement of the poor in these circumstances; a call on the early Christians to help the poor and finally to strengthen them. The research, however, culminates in the metaphorical use of 'rich' by James: 'Has not God chosen the poor in the world to be rich in faith and to be heirs of the kingdom ...?' (Ja 2:5; italics author's emphasise)

\section{Metaphoric use of economic concepts and terminology}

\section{Richness used metaphorically}

'Listen, my beloved brothers. Has not God chosen the poor in the world to be rich in faith and to be heirs of the kingdom ...' (Ja 2:5; italics author's emphasise). In this text, James adds an additional argument as to why his readers should not flatter the rich and despise the poor (Loh \& Hatton 1997:67). Again James begins a discussion with a rhetorical question, 'Has God not chosen the poor to be rich in faith ${ }^{95}$...?' using the interrogative ov $\chi$ as in 2:4. This question about the poor parallels with the rich who are dialectically posed against

93.rvpuvoi, 'naked' may not mean unclothed but inadequately clothed, such as only having on an undergarment; cf. 1 Samuel 19:24; Job 22:6; Isaiah 58:7; Amos 2:16 Matthew 25:36. Cf. also Loh \& Hatton 1997:85.

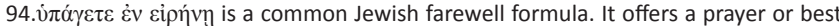
wishes to the person who is leaving. It is also used as a sign of ending an encounter, or sending someone off. It is therefore equivalent to saying 'goodbye' to someone (Loh \& Hatton 1997:8). Also cf. Judges 18:6; 1 Samuel 1:17; 20:42; 2 Samuel 15:9; Mark 5:34; Luke 7:50; Acts 16:36.

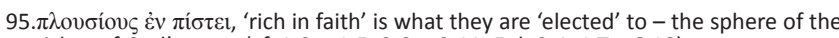
riches of God's grace (cf. 1 Cor 1:5; 2 Cor 9:11; Eph 2:4; 1 Tm 6:18). 
them ${ }^{96}$ in order to drive home the point James is trying to make here. In each of these rhetorical questions (2:5-7), the participle mode of the verb indicates the expectation of an affirmative answer. The church knows very well that God is in favour of the poor and had chosen ${ }^{97}$ them. Mills (1997:\$8) argues that the believer should live in the spiritual realm and thus elevate themself above worldly values (this harmonises with 1:27).

This concept of election is deeply rooted in both Jewish and Christian thought. God chose Israel (Dt. 4:37; 7:7; 14:2) and thus the Jews thought of themselves as God's elect (at times to their own detriment; cf. Coenen 1975:539). Likewise God has chosen groups for his new people (Ac 13:17; 15:7; $1 \mathrm{Pt}$. 2:9; Eph 1:4), and one of the favoured groups is 'the poor'. God chooses them so that his might is evident, and therefore, the glory can only be attributed to him (Mills 1997:\$8). This election is based on the Old Testament passages in which God is said to care for the poor (e.g. Dt 16:3; 26:7).

The above results in the fact that 'poor' becomes a terminus technicus for the pious, not only in the Old Testament but also in the intertestamental and rabbinic literature. ${ }^{98}$ This development constitutes the background of Jesus' declaration of the election of the poor (cf. Mt 5:3; Lk 6:20). Thus the reversal here is incongruent: The poor remain materially poor, but they become rich in faith (cf. McKnight 2011:195). This understanding agrees with that of Loh \& Hatton (1997:68). According to them, when God selects poor people, 'he makes them to be rich in faith or 'to become rich in faith,' not rich according to the worldly standards'. Consequently we can understand rich in faith to mean 'rich in having an abundance of faith'. Accordingly this phrase can also be understood in the sense of 'rich by reason of faith'. Therefore, it may be rendered as 'to become spiritually rich because of their faith'.

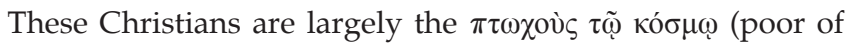
the world -2:5), a situation which is true everywhere (e.g. 1 Cor 1:26) but particularly in Palestine (Gl 2:10; 2 Cor 8:9; Ac 11:29). God has chosen these poor, 'rich in the sphere of faith'99 (using a figure of speech), to be 'heirs of the kingdom' ${ }^{100}$ The world sees only their poverty; God sees their exalted state because of their election to eschatological exaltation. They are the ones who love him and thus receive his promise (cf. the comment on 1:12). The reference to 'the poor' has, as Bammel (1982:911) observes, acquired a religious quality. This is now virtually a name for the true believers (cf. McKnight 2011:194). ${ }^{101}$ It does so without losing the quality

96.See 2:6-7 discussed earlier in the article.

97.Loh \& Hatton (1997:67) critically point out that 'The term selected by a translato should not have the negative sense that God is picking out or selecting the good from among the bad, and that he will throw away the bad.'

98.See Sir 10:22-24; Ps. Sol. 5; 1 Enoch 108:7-15; cf. Bammel 1982:[6]895-898.

99.Although one does not know whether they had much faith, Dibelius $(1976: 136)$ is of the opinion that the contrast is explained by the next accusative as that of real eschatological wealth.

100.In other words, the kingdom of God promised to the poor in Luke 6:20; Matthew $5: 3 ;$ Cf. 25:34; 1 Corinthians 6:9, 10; Galatians 5:21.

101.The Matthean version of the beatitude in Matthew 5:3 is an accurate interpretation in part. of material poverty. It is a materially poor person who has been discriminated against. Out of their poverty, God brings glory by the bestowal of his heavenly riches. They will be heirs of the kingdom. The poor receiving the kingdom is also a concept that appears often in Jesus' teachings. ${ }^{102}$

\section{Conclusion}

In this research it became evident that the letter of James is saturated and closely interwoven with data on labour relations and socioeconomic matters. Cyclic reasoning on these matters occurs throughout the letter. Every time that James addresses a matter, he incorporates new aspects.

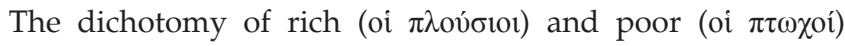
constitutes a 'real concern for James'. The major issue for him is the antithesis between these two economic classes. Socioeconomic matters and labour relations are spelled out with regard to relationships in terms of how the rich behave towards the poor and how the poor are urged to behave during these circumstances.

Some of these social and labour relations becomes evident when James reprimands the Christians and makes them feel guilty for their partial favouritism of the rich above the poor in their communities. All this is written to rebuke and to teach the Christians not to discriminate between the rich and the poor. James addresses this problem from different perspectives in order to give a comprehensive picture thereof.

According to his presentation and address of the various strata of these problems, it seems as if the paraenetic material was not directed at the social structures and problems of a specific group of addressees. For precisely where James makes reference to the communities themselves, the cases discussed in the letter give the impression of being exemplary of real occurrences ${ }^{103}$ in his own community as well as those to whom he has written.

James sees nothing wrong in being rich. Nowhere does he express himself explicitly against the phenomenon to be rich' (see Richardson 2001:75). However, we saw that he condemns the rich for their unrighteous deeds in obtaining their riches and for their selfish attitudes. His problem regarding rich people is threefold: (1) it concerns the way these people became rich, (2) their negative attitudes and unrighteous deeds towards the poor, now that they are rich, and (3) their selfish desires for wealth and arrogant selfesteem.

For James, such a way of life of unrighteous deeds and attitudes by the rich against the poor conveys certain consequences. Consistently, he pointed out that, for both the rich and poor, these consequences have a strong eschatological undertone. For cruel, rich people it will be a day ( $\pi \alpha \rho$ ovбí $\alpha$ ) of judgement and for the poor people a day of relief.

102.Se Loh \& Hatton (1997:68) for a thorough discussion on the kingdom concept and background.

103. See footnote 37 for a possible hypothetical situation and footnote 40 for a possible rhetorical device. 


\section{Acknowledgements Competing interests}

The author declares that he has no financial or personal relationship(s) which may have inappropriately influenced him in writing this paper.

\section{References}

Adamson, J.B., 1976, The epistle of James, Eerdmans, Grand Rapids.

Balz, H.R. \& Schneider, G., 1993, Exegetical dictionary of the New Testament (Translation of Exegetisches Wörterbuch zum Neuen Testament), Eerdmans, Grand Rapids.

Bammel, E., 1982, ' $\pi \tau \omega \chi \grave{c} \zeta$ ', in G. Kittel \& G. Friedrich (eds.), Theological Dictionary of the New Testament, vol. 6, pp. 885-915, Kohlhammer Verlag, Stuttgart.

Beyer, H.W., 1979, 'B $\lambda \alpha \sigma \varphi \eta \mu i^{\alpha} \alpha$ ', in G. Kittel \& G. Friedrich (eds.), Theological Dictionary of the New Testament, vol. 1, pp. 621-625, Eerdmans, Grand Rapids.

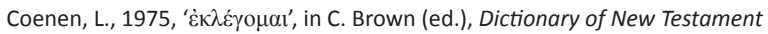
Theology, vol. 1, pp. 536-542, Paternoster Press, Exeter.

Danker, F.W., 2000, A Greek-English lexicon of the New Testament and other early Christian literature, 6th edn., University of Chicago Press, Chicago.

Davids, P.H., 1982, The epistle of James: A commentary on the Greek Text, Eerdmans, Grand Rapids.

Dibelius, M., 1976, James: A commentary on the epistle of James, Pickering \& Inglis, London.

Falkenroth, U. \& Brown, C., 1976, ' $\mu \alpha \kappa \rho \circ \theta v \mu \varepsilon \omega^{\omega}$ ', in C. Brown (ed.), Dictionary of New Testament Theology, vol. 2, pp. 768-776, Paternoster Press, Exeter.

Friberg, T., Friberg, B. \& Miller, N.F., 2000, Analytical lexicon of the Greek New Testament (Baker's Greek New Testament library), vol. 4, Baker Books, Grand Rapids.

Geyser, A.S., 1975, 'The letter of James and the social condition of his addressees', Neotestamentica 9, 25-33.

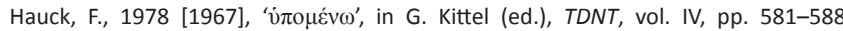
Eerdmans, Grand Rapids.

Horst, F. 1978, ' $\mu \alpha \kappa \rho о \theta v \mu \varepsilon \omega^{\prime}$ ', in G. Kittel \& G. Friedrich (eds.), Theological Dictionary of the New Testament, vol. 6, pp. 374-387, Eerdmans, Grand Rapids.

Johnson, L.T., 1982, 'The Uue of Leviticus 19 in the letter of James', Journal of Biblical Literature 101, 391-401.

Keck, L.E., 1965, 'The poor', Zeitschrift für neutestamentliche Wissenschaft 56 100-129.

Kistemaker, S.J., 1984, 'New Testament commentary: Exposition of the epistle to the Hebrews', Baker Book House, Grand Rapids.

Lea, T.D., 1999, Hebrews, James, Holman New Testament Commentary, vol. 10, Broadman \& Holman Publishers, Nashville.

Liddell, H.G. \& Scott, R., 1996, Greek-English lexicon, Oxford University Press, Oxford.
Loh, I-J. \& Hatton, H., 1997, A handbook on the letter from James, UBS Handbook Series, United Bible Societies, New York.

Lohse, E., 1976, ' $\pi \rho \circ \sigma \omega \pi \mathrm{o} \lambda \eta \pi \tau \varepsilon \dot{\varepsilon} \omega$ ', in G. Kittel \& G. Friedrich (eds.), Theological Dictionary of the New Testament, vol. 6, pp. 779-780, Eerdmans, Grand Rapids.

Louw, J.P. \& Nida, E.A., 1996, Greek-English lexicon of the New Testament: Based on semantic domains, electronic edn. of the 2 nd edn., United Bible Societies, New York.

MacArthur, J., 1998, James, MacArthur New Testament Commentary, Moody Press, Logos, Chicago.

Martin, R.P. 2002, James, World Biblical Commentary, vol. 48, Word Incorporated, Dallas.

Maynard-Reid, P.U., 1987, Poverty and wealth in James, Maryknoll, New York.

McKnight, S., 2011, The letter of James, Eerdmans, Grand Rapids.

Mills, M.S., 1997, James, 3 E Ministries, Dallas.

Moo, D.J., 2000, The letter of James, The Pillar New Testament Commentary, Eerdmans, Grand Rapids.

Noack, B., 1964, 'Jakobus wider die Riechen', Studia Theologica 18, 10-25.

Philo, 1995a, 'Allegoric interpretation III', in The works of Philo: Complete and unabridged, transl. C.D. Yonge, pp. 50-80, Hendrickson, Peabody.

Philo, 1995b, 'De Virtutibus', in The works of Philo: Complete and unabridged, transl. C.D. Yonge, pp. 640-664, Hendrickson, Peabody.

Richardson, K.A., 2001, James, The New American Commentary, vol. 36, electronic edn., Broadman \& Holman Publishers, Nashville.

Ropes, J.H., 1961, A critical and exegetical commentary on the epistle of St. James, C. Scribner's Sons, New York.

Rostovtzeff, M., 1971, The social and economic history of the Roman empire, rev. P.M. Frazer, vol. 1,. Clarendon, Oxford.

Schökel, L.A., 1973, 'James 5:2 [sic] and 4:6', Biblica 54, 73-76.

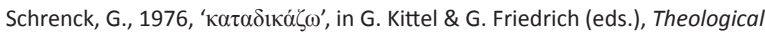
Dictionary of the New Testament, vol. 3, pp. 621-622, Eerdmans, Grand Rapids.

Sidebottom, E.M., 1967, James, Jude, and 2 Peter, Attic, Greenwood.

Stegemann, E. \& Stegemann, W., 1999, The Jesus movement: A social history of its first century, T\&T Clark, Edinburgh.

Stulac, G.M., 1990, Who are 'the rich' in James? Presbyterion 16, 89-102.

Swanson, J., 1997, Dictionary of Biblical Languages With Semantic Domains: Greek (New Testament) electronic edn., Logos Research Systems, Inc., Oak Harbor.

Van der Merwe, D.G., 2010, 'Rich man, poor man in Jerusalem according to the letter of James,' Acta Patristica Et Byzantina 21(1), 18-46.

Van der Merwe, D.G., 2009, 'Rich man, poor man in Jerusalem according to the letter of James', Acta Patristica et Byzantina 20, 89-108.

Ward, R.B., 1969, 'Partiality in the assembly: James 2:2-4', Harvard Theological Review 62, 87-97

Winston, W., 1996, The works of Josephus: Complete and unabridged, Hendriksen, Peabody.

Zodiates, S., 2000, The complete word study dictionary: New Testament, electronic edn., AMG Publishers, Chattanooga. 